Research Article

\title{
Model Action Plan for the Implementation of Vector Surveillance at the International Airports/ Seaports: Point of Entries (PoEs)
}

\author{
SN Sharma, Sujeet K Singh
}

National Centre for Disease Control, 22 Sham Nath Marg, Delhi, India.

DOI: https://doi.org/10.24321/0019.5138.202139

I $\mathbf{N}$ F $\mathbf{O}$

\section{Corresponding Author:}

SN Sharma, National Centre for Disease Control, 22 Sham Nath Marg, Delhi, India.

E-mail Id:

drsns.nvbdcp@gmail.com

Orcid Id:

https://orcid.org/0000-0001-8569-1661

How to cite this article:

Sharma SN, Singh SK. Model Action Plan for the Implementation of Vector Surveillance at the International Airports/ Seaports: Point of Entries (PoEs). J Commun Dis. 2021;53(3):60-68.

Date of Submission: 2021-08-20

Date of Acceptance: 2021-09-04

\author{
$\begin{array}{llllllll}\mathbf{A} & \mathbf{B} & \mathbf{S} & \mathbf{T} & \mathbf{R} & \mathbf{A} & \mathbf{C} & \mathbf{T}\end{array}$
}

As per International Health Regulations (2005), all the International airports and seaports are to be kept free from the vectors, which may cause public health hazards through transmission of pathogen through them. The country is presently connected by air, sea and road through porous borders. Due to the new challenges/ requirements brought about by the IHR (2005), necessary efforts are being made in India to ensure effective vector surveillance and control at POEs. It is also intended for use by the concerned port health officers, airport health officers, border health officers, regulators, port operators, and other competent authorities in charge of implementing the IHR (2005) at points of entry. This present SoP/ guidelines regarding vector surveillance and control may be used as a basis for the development of a management plan for preparing and performing vector surveillance and applying public health measures within the framework of the IHR (2005). The primary aim of developing model action plan is to assist public health authorities at PoE in strengthening core capacities and managing vector surveillance and control programmes by providing technical guidance on the optimal use of resources, planning, monitoring, and decision-making. There seems to be an urgent need for the vector control experts to be engaged at each international airport/ seaports due to fast expansions of the areas of the airports/ seaports and in view of receptivity and presence of breeding potential habitats of Aedes mosquitoes.

Keywords: IHR, PoE, VBDs, WHO

\section{Introduction}

Vector Borne Disease control across international borders is one of the important public health issue. India is having international ground crossings and bordering districts with Nepal, Bhutan, Myanmar, and Bangladesh. The country is connected with air and water with other part of world with entry points at airports and seaports. Transmission dynamics across borders are generally similar to Indian climatic conditions. There has been heavy international travel with influx of passengers from endemic countries with the presence of Yellow Fever, Zika, Dengue and Chikungunya. ${ }^{1,2}$

Vector-borne diseases (such as malaria, dengue, chikungunya, Zika virus, yellow fever) are reported in over 100 countries and put up to $60 \%$ of the world's population at risk of infection; more than 500 million cases are reported 
each year. ${ }^{6}$ International travel and transport play an important role in the rapid spread of vector-borne diseases all over the world - as borders become more porous and the speed and extent of travel and shipping increase, so too does the potential of the spread of reservoirs and pathogens related to vector-borne diseases.

There are presently 22 international airports and 12 seaports in the country, which act as point of entry and IHR regulations are to be strictly undertaken.

As per IHR (2005) Regulations, it is stated that the airports, and ports that shall develop core capacities requirements, and where justified for public health reasons, may also designate ground crossing. One of the underlined areas is capacity building for vector surveillance and control at PoEs. The present model action plan for implementation of Vector Surveillance at the International Airports/ Seaports: Point of Entries (PoEs) is aimed at assisting the Airport and sea port health authorities to comply with the obligations of the IHR (2005). There is need for providing the technical support or developing a comprehensive programme for systematic monitoring of vectors and an integrated vectorcontrol plan at points of entry. ${ }^{3-5}$

The countries shall establish programmes to control vectors that may transport infectious agents constituting a public health risk $^{6,7}$. Such programmes must ensure that vectors are controlled to a minimum distance of 400 meters from those areas of point-of-entry facilities that are used for operations involving travelers, conveyances, containers, cargo, and postal parcels, with extension of the minimum distance if vectors with a greater range are present.

Model Action Plan for Vector Surveillance for Dengue/ CHK/ Yellow Fever at International Airports/ Seaports (Point of Entries).

There are two components of Model Action Plan i.e. Macro and Micro Action Plan for proper planning and implementation of activities. The details of these two components are as follows.

1. Macro Plan for Vector Surveillance at PoEs.

The following steps may be followed while framing the macro-action plan for vector surveillance activities.

- $\quad$ Assess \& Evaluate Receptivity and Vulnerability:

- Local Epidemiological Situation

- Local Entomological Updates

- Local Health authorities : 400 Perimeter

- Local Environmental Conditions

- Make a risk assessment : Periodic Disease and Vector Assessment

- Establish Vector Surveillance Plan

- Implementation of the Plan
- Monitoring and Evaluation

- Emergency Plan

2. Micro Action Plan for Vector Surveillance at PoEs. The following components may be included in the micro surveillance and vector control plans.

- Situation Analysis

- Identify Risk Factors

- Local entomological situation

- Infra-structure Assessment (Requirement/ Available

- $\quad$ Training (Skill Competency)

- Budgetary Requirements

- Requirements of Insecticides/larvicides/ equipment's

- IEC/BCC Activities

- Inter-sectoral Coordination

- Reconnaissance of the PoE area and surrounding 400-metre perimeter or wider

- Vector Surveillance

- Vector Management

- Monitoring \& Supervision

\section{Components of Vector Surveillance Plan}

The airport/ seaport area may be divided into small sectors based on building or non-building area. Weekly visits may be planned to search all the sectors as per the beat programme to be covered on assigned days by the respective teams. Field operation should focus on the presence and identification of target vector in a particular habitat. Field samples may be collected from field and transported to the laboratory for further processing.

\section{Demographic Situation}

- Name of the Airport/ Seaport:

Location:

- Area size: (Sq. Kms):

- Map (showing building, workshop, cargo, fire station etc.)

- Breeding habitats (Open and Building areas)

- No. of International flights/ passengers from Yellow Fever Endemic Countries per week/ month

\section{Situation Analysis}

Table I.VBDs in the District / Town

\begin{tabular}{|c|l|l|l|l|l|}
\hline Diseases & Malaria & Dengue & Chikungunya & Zika & JE \\
\hline 2015 & & & & & \\
\hline 2016 & & & & & \\
\hline 2017 & & & & & \\
\hline 2018 & & & & & \\
\hline 2019 & & & & & \\
\hline 2020 & & & & & \\
\hline 2021 & & & & & \\
\hline
\end{tabular}




\section{Identify Risk Factors}

1. International Travel

- Month wise list of passengers arriving from Yellow fever endemic countries

- Month wise list of passengers going to Yellow fever endemic countries

2. Local Entomological Indices

- Vector breeding potential in and around $400 \mathrm{mts}$. Perimeter of airport/ seaport

3. Endemicity around Airport

\section{Local Entomological Situation}

Table 2.Entomological Situation (3-5 Years)

\begin{tabular}{|c|c|c|c|c|c|}
\hline Sr. No. & Town / Ward name & Date of survey & HI/PI & CI & BI \\
\hline 1. & & & & & \\
\hline 2. & & & & & \\
\hline 3. & & & & & \\
\hline 4. & & & & & \\
\hline 5. & & & & & \\
\hline
\end{tabular}

\section{Infrastructure Assessment}

Table 3.Present Status of Human Resource (Sanctioned \& Vacant)

\begin{tabular}{|c|l|l|l|l|}
\hline Regular posts & Required & Sanctioned & In-position & Vacant \\
\hline APHO/ PHO & & & & \\
\hline Medical officers & & & & \\
\hline Vector Control Officer/ entomologist & & & & \\
\hline Public health inspector & & & & \\
\hline Insect collectors & & & & \\
\hline Filed workers & & & & \\
\hline Any other category (please specify) & & & & \\
\hline
\end{tabular}

\section{Training/ Capacity Building}

Table 4.Training/ Capacity Building

\begin{tabular}{|c|c|c|c|c|c|c|c|c|c|}
\hline & & Cost & Trained in & \multicolumn{5}{|c|}{ To be Trained in Current year } \\
\cline { 6 - 10 } No & Trainings & $\begin{array}{c}\text { per } \\
\text { batch }\end{array}$ & $\begin{array}{c}\text { Previous } \\
\text { year (no) }\end{array}$ & $\begin{array}{c}\text { Q1 } \\
\text { (no) }\end{array}$ & $\begin{array}{c}\text { Q2 } \\
\text { (no) }\end{array}$ & $\begin{array}{c}\text { Q3 } \\
\text { (no) }\end{array}$ & $\begin{array}{c}\text { Q4 } \\
\text { (no) }\end{array}$ & $\begin{array}{c}\text { Total } \\
\text { (no) }\end{array}$ & $\begin{array}{c}\text { Total } \\
\text { cost (Rs) }\end{array}$ \\
\hline 1. & APHOs / PHOs / VCOs / Entomologists & & & & & & & & \\
\hline 2. & Medical officers & & & & & & & & \\
\hline 3. & Laboratory technicians & & & & & & & & \\
\hline 4. & Health supervisors (M) & & & & & & & & \\
\hline 5. & Health workers (M) & & & & & & & & \\
\hline 6. & Others specify & & & & & & & & \\
\hline & Total & & & & & & & & \\
\hline
\end{tabular}




\section{Budgetary Requirements}

Table 5.Budgetary Requirements

\begin{tabular}{|c|c|c|c|}
\hline S. No. & Activity & Budget available (in Rs.) & Budget Required (in Rs.) \\
\hline 1. & Human Resource & & \\
\hline 2. & Equipment's & & \\
\hline 3 & Larvicides/ Insecticides & & \\
\hline 4. & Others (please specify) & & \\
\hline
\end{tabular}

\section{Commodity Requirement}

Table 6.Commodity Requirement

\begin{tabular}{|c|c|c|c|c|}
\hline \multirow{2}{*}{ Item } & $\begin{array}{c}\text { Previous year's } \\
\text { utilization }\end{array}$ & $\begin{array}{c}\text { Requirement for } \\
\text { current year }\end{array}$ & Balance available & $\begin{array}{c}\text { Net requirement } \\
\text { (2-3) }\end{array}$ \\
\cline { 2 - 5 } & $\mathbf{1}$ & $\mathbf{2}$ & $\mathbf{3}$ & $\mathbf{4}$ \\
\hline Temephos 50\% (in Itrs.) & & & & \\
\hline B.t.i. (WP/AS) & & & & \\
\hline Diflubenzuron 5\% (in Itrs) & & & & \\
\hline Pyrethrum Extt. 2\% (in Itrs.) & & & & \\
\hline Any other (Please specify) & & & & \\
\hline
\end{tabular}

\section{IEC Activities}

Table 7.IEC Activities

\begin{tabular}{|c|c|c|c|c|c|c|c|c|c|}
\hline \multirow{2}{*}{$\begin{array}{l}\text { S. } \\
\text { No. }\end{array}$} & \multirow{2}{*}{ Activities } & \multirow{2}{*}{$\begin{array}{l}\text { Unit cost } \\
\text { (Rs) }\end{array}$} & \multirow{2}{*}{$\begin{array}{l}\text { Previous } \\
\text { year (no) }\end{array}$} & \multicolumn{6}{|c|}{ Current year } \\
\hline & & & & Q1 (no) & Q2 (no) & Q3 (no) & Q4 (no) & Total (no) & Total cost (Rs) \\
\hline A. & \multicolumn{9}{|l|}{ Print media } \\
\hline 1. & Posters & & & & & & & & \\
\hline 2. & Hoardings & & & & & & & & \\
\hline B. & \multicolumn{9}{|l|}{ Electronic media } \\
\hline 4. & TV campaigns & & & & & & & & \\
\hline 5. & Radio campaigns & & & & & & & & \\
\hline C. & \multicolumn{9}{|l|}{ Community level } \\
\hline 6. & Health camps & & & & & & & & \\
\hline 7. & $\begin{array}{l}\text { Village level } \\
\text { awareness } \\
\text { camps for IRS }\end{array}$ & & & & & & & & \\
\hline 8. & Others (specify) & & & & & & & & \\
\hline & Total & & & & & & & & \\
\hline
\end{tabular}

Reconnaissance of the PoE Area and Surrounding 400-metre Perimeter or Wider

Reconnaissance of the PoE area and surrounding 400-metre perimeter may be carried out during pre-monsoon and post monsoon period for Mapping of breeding potential sites. The number and type of breeding potential areas would help in proper planning and calculating the logistics requirements with regard to vector management at the airport/seaport areas.

\section{Entomological Surveillance}

The entomological surveillance need to be strengthened at all international airports/ seaports to ensure zero tolerance for aedes breeding. The concerned airports/ seaports authorities should strengthen the available staff of the 
entomological teams with proper training, monitoring and supervision. The teams should undertake fortnightly field visits for vector surveillance in their respective areas. The total area of the airport /seaports may be divided into different zones for proper understanding and undertaking vector surveillance. All the breeding potential areas need to be mapped for planning proper source reduction and anti-larval activities.

The entomological information collected by the surveillance teams during fortnight visits may be collected on the prescribed format given below.

Table 8.Reconnaissance of the PoE Area and Surrounding 400-metre Perimeter or Wider

\begin{tabular}{|c|c|c|c|c|c|c|c|}
\hline \multirow{2}{*}{ Sr. No. } & \multirow{2}{*}{ Zone (Site area) } & \multicolumn{6}{|c|}{ No. of breeding potential areas and size (in meters) } \\
\hline & & Plastic & Iron & Cement & Rubber & Natural & Others (Specify) \\
\hline 1. & & & & & & & \\
\hline 2. & & & & & & & \\
\hline 3. & & & & & & & \\
\hline 4. & & & & & & & \\
\hline 5. & & & & & & & \\
\hline
\end{tabular}

Table 9.Plan for Vector Surveillance Activities at Airport / Seaport

\begin{tabular}{|c|c|c|c|}
\hline S. No. & Zone (Sites) & Visit planned (Day of month) & Observations and actions proposed \\
\hline 1. & & & \\
\hline 2. & & & \\
\hline 3. & & & \\
\hline 4. & & & \\
\hline
\end{tabular}

Table I0.Fortnightly Plan for Mosquito Seasonal Surveillance at Airport \& Seaport

\begin{tabular}{|c|c|c|c|c|c|c|c|c|c|c|c|c|c|c|c|c|c|c|c|c|c|c|c|c|c|c|c|}
\hline & & 屯 & z & \multicolumn{24}{|c|}{ Mosquito management schedule } \\
\hline $\begin{array}{l}z \\
\text { vi }\end{array}$ & $\stackrel{ \pm}{\Delta}$ & 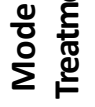 & 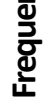 & 1 & 2 & 3 & 4 & 5 & 6 & 7 & 8 & 9 & 10 & 11 & 12 & 13 & 14 & 15 & 16 & 17 & 18 & 19 & 20 & 21 & 22 & 23 & 24 \\
\hline 1. & & & & & & & & & & & & & & & & & & & & & & & & & & & \\
\hline 2. & & & & & & & & & & & & & & & & & & & & & & & & & & & \\
\hline 3. & & & & & & & & & & & & & & & & & & & & & & & & & & & \\
\hline 4. & & & & & & & & & & & & & & & & & & & & & & & & & & & \\
\hline
\end{tabular}

Table I I. Entomological Surveillance Format

\begin{tabular}{|c|c|c|c|c|c|c|c|c|c|c|c|c|c|c|c|c|c|c|c|}
\hline \multirow{2}{*}{$\begin{array}{l}\dot{0} \\
\dot{n}\end{array}$} & \multirow{2}{*}{ 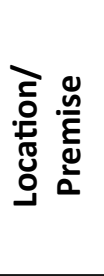 } & \multicolumn{2}{|c|}{ ㅎํㅇ } & \multicolumn{2}{|c|}{ 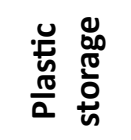 } & \multicolumn{2}{|c|}{ 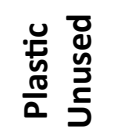 } & \multicolumn{2}{|c|}{ 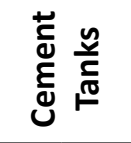 } & \multicolumn{2}{|c|}{ 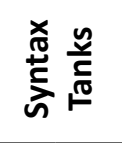 } & \multicolumn{2}{|c|}{ 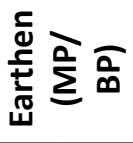 } & \multicolumn{2}{|c|}{ 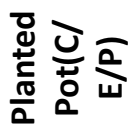 } & \multicolumn{2}{|c|}{ 응 } & \multicolumn{2}{|c|}{$\begin{array}{l}\frac{n}{d} \\
\frac{5}{0}\end{array}$} \\
\hline & & 宅 & 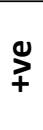 & 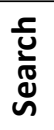 & 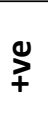 & 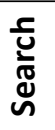 & $\stackrel{\$}{\Psi}$ & 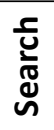 & $\stackrel{叉}{\Psi}$ & 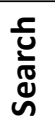 & $\stackrel{\searrow}{\ddagger}$ & 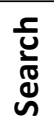 & $\stackrel{\$}{+}$ & 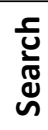 & $\stackrel{\$}{\Psi}$ & 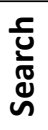 & $\stackrel{Ð}{\ddagger}$ & 宅 & $\stackrel{\$}{\Psi}$ \\
\hline 1. & & & & & & & & & & & & & & & & & & & \\
\hline 2. & & & & & & & & & & & & & & & & & & & \\
\hline 3. & & & & & & & & & & & & & & & & & & & \\
\hline 4. & & & & & & & & & & & & & & & & & & & \\
\hline 5. & & & & & & & & & & & & & & & & & & & \\
\hline 6. & & & & & & & & & & & & & & & & & & & \\
\hline 7. & & & & & & & & & & & & & & & & & & & \\
\hline
\end{tabular}




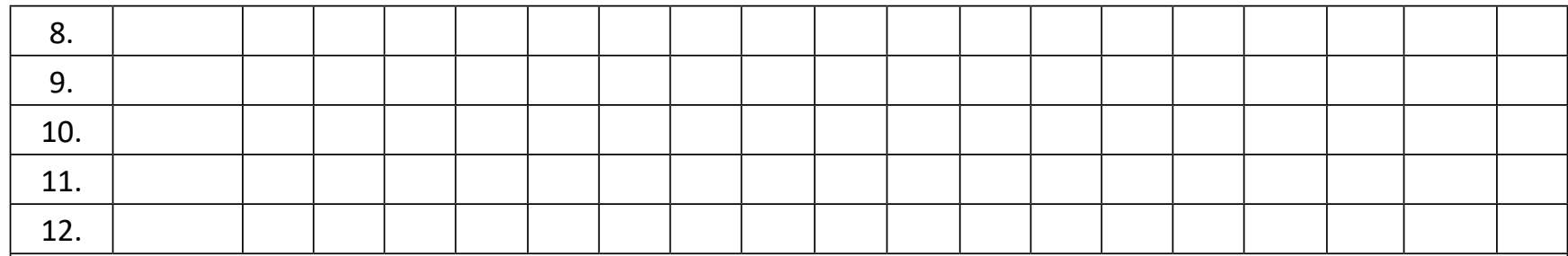

MP - Mud Pot, BP - Bird Pot; C - Cement pot, E - Earthen pot, P - Plastic pot; Solid waste* includes tyres, unused cup, broken glasses.

No. of Premises Checked $(A)=\quad$ No. of Premises Positive $(B)=\quad$ No. of Containers Checked $(C)=\quad$ Premises Index $=[B \times 100 / A]=$

No. of Containers Positive $(\mathrm{D})=$ Container Index $=[\mathrm{D} \times 100 / \mathrm{C}]=\mathrm{Bl}=[\mathrm{D} \times 100 / \mathrm{A}]=\quad$ No. of Pupae $(\mathrm{P})=$

Pupal Index $=[\mathrm{P} / \mathrm{Ax} 100]=$

Table I2.NVBDCP Approved Larvicides Formulations and Dosages

\begin{tabular}{|c|c|c|c|c|c|c|c|c|c|}
\hline \multirow[b]{2}{*}{$\begin{array}{l}\text { S. } \\
\text { No. }\end{array}$} & \multirow[b]{2}{*}{$\begin{array}{l}\text { Name of } \\
\text { larvicide }\end{array}$} & \multirow[b]{2}{*}{$\begin{array}{l}\text { Commercial } \\
\text { formulation }\end{array}$} & \multirow{2}{*}{$\begin{array}{c}\text { Preparation } \\
\text { of ready } \\
\text { to spray } \\
\text { formulation }\end{array}$} & \multicolumn{3}{|c|}{ Dosage } & \multirow[b]{2}{*}{$\begin{array}{l}\text { Frequency } \\
\text { of } \\
\text { application }\end{array}$} & \multirow[b]{2}{*}{$\begin{array}{l}\text { Equipment } \\
\text { required }\end{array}$} & \multirow[b]{2}{*}{ Remarks } \\
\hline & & & & $\begin{array}{c}1 \\
\text { square } \\
\text { meter }\end{array}$ & \begin{tabular}{|c|}
50 \\
linear \\
meter
\end{tabular} & $\begin{array}{c}\text { Per } \\
\text { hectare }\end{array}$ & & & \\
\hline 1. & $\begin{array}{c}\text { Temephos } \\
\text { (Abate) }\end{array}$ & $50 \% \mathrm{EC}$ & $\begin{array}{c}2.5 \text { c.c. in } \\
10 \text { Liters of } \\
\text { potable } \\
\text { water }\end{array}$ & 20 c.c. & $\begin{array}{c}1 \\
\text { Liter }\end{array}$ & $\begin{array}{l}200 \\
\text { Liters }\end{array}$ & -do- & $\begin{array}{c}\text { Knapsack/ } \\
\text { Hand } \\
\text { compression } \\
\text { Sprayer } \\
\end{array}$ & $\begin{array}{l}\text { Can be } \\
\text { applied in } \\
\text { clean } \\
\text { water }\end{array}$ \\
\hline 2. & $\begin{array}{c}\text { Bacillus } \\
\text { thuringiensis } \\
\text { var } \\
\text { israelensis } \\
\text { WP } \\
\text { Bacillus } \\
\text { thuringiensis } \\
\text { var }\end{array}$ & $\begin{array}{c}\text { Wettable } \\
\text { Powder }\end{array}$ & $\begin{array}{c}5 \mathrm{Kg} \text { in } 200 \\
\text { liters of } \\
\text { Water } \\
1 \text { liter in } \\
200 \text { liters of } \\
\text { water }\end{array}$ & - & - & $\begin{array}{c}5 \mathrm{Kg} . \\
1 \text { liters }\end{array}$ & Fortnightly & $\begin{array}{l}\text { Knapsack/ } \\
\text { Hand } \\
\text { compression } \\
\text { sprayer } \\
\text { Knapsack/ } \\
\text { Hand }\end{array}$ & $\begin{array}{c}\text { For both } \\
\text { clean and } \\
\text { non- } \\
\text { potable } \\
\text { polluted } \\
\text { water } \\
\text { Clean } \\
\text { Water }\end{array}$ \\
\hline 3. & $\begin{array}{l}\text { israelensis } 12 \\
\text { Aqueous } \\
\text { Suspension } \\
\text { (12AS) }\end{array}$ & $\begin{array}{l}\text { Aqueous } \\
\text { Suspension }\end{array}$ & $\begin{array}{c}2 \text { liter in } \\
200 \text { liters of } \\
\text { water } \\
100 \text { gms in } \\
100 \text { liters } \\
\text { of water }\end{array}$ & - & - & $\begin{array}{c}2 \text { liters } \\
25 \mathrm{gm} \\
\text { a.i }\end{array}$ & Weekly & $\begin{array}{l}\text { compression } \\
\text { Sprayer } \\
\text { Knapsack/ } \\
\text { Hand }\end{array}$ & $\begin{array}{l}\text { Polluted } \\
\text { Water } \\
\text { Clean } \\
\text { Water }\end{array}$ \\
\hline \multirow{3}{*}{4.} & \multirow{3}{*}{$\begin{array}{l}\text { Diflubenzuron } \\
25 \% \text { WP }\end{array}$} & \multirow{3}{*}{$\begin{array}{c}25 \% \\
\text { Wettable } \\
\text { Powder }\end{array}$} & \multirow{3}{*}{$\begin{array}{c}200 \text { gms in } \\
100 \text { Litres } \\
\text { of water }\end{array}$} & \multirow{3}{*}{ - } & \multirow{3}{*}{ - } & \multirow{3}{*}{$\begin{array}{l}50 \mathrm{gm} \\
\mathrm{a} . \mathrm{i} \\
2 \mathrm{~kg} .\end{array}$} & \multirow{3}{*}{ Weekly } & compression & \\
\hline & & & & & & & & Sprayer & $\begin{array}{c}\text { Polluted } \\
\text { Water }\end{array}$ \\
\hline & & & & & & & & Granular & $\begin{array}{l}\text { Clean } \\
\text { Water }\end{array}$ \\
\hline 5. & Pyriproxyfen & $\begin{array}{l}0.5 \% \\
\text { granular }\end{array}$ & $\begin{array}{l}\text { Ready-to- } \\
\text { use }\end{array}$ & - & - & $4 \mathrm{~kg}$ & 3 weekly & $\begin{array}{c}\text { Applicator / } \\
\text { hand } \\
\text { broadcast }\end{array}$ & $\begin{array}{l}\text { Polluted } \\
\text { water }\end{array}$ \\
\hline
\end{tabular}

\section{Vector Management}

All efforts may be made for undertaking source reduction of the breeding potential habitats at the respective areas. However, the larger and permanent water bodies need to be treated with appropriate conventional larvicides as approved by Government of India.

\section{Monitoring \& Supervision}

Monitoring and supervision is the key component of any programme implementation in the field situation. It would be required weekly/ fortnightly with regard to the dengue vector surveillance at all tiers of supervisory level. It should be ensured that the management of information system 
in the prescribed formats is in place at the concerned airport/ seaport.

\section{Rodents Surveillance}

Rodent surveillance is accomplished to determine rodent presence and infestation levels in in the airport/ seaport premises.

Surveillance programmes that monitor disease activity in susceptible rodent populations alert public health authorities to increased human plague risks, thus allowing prevention and control programmes to be implemented before human cases occur. Surveillance in this case is usually done by visual survey for faeces, damage, rub marks and sightings of dead or live rodents, or sometimes with live traps, snap traps or glue boards. Commensal rodents usually do not cause the problems in the field as they normally do at permanent installations, but other wild rodents may become nuisances or serve as reservoirs of disease. Rodents, as well as their ectoparasites, occasionally must be collected to determine the presence of known, or perhaps new, vector-reservoir systems.

\section{Rodent Sampling Techniques}

The most common techniques for monitoring disease in rodent population include:

- Collecting and examining dead rodents

- Monitoring activity among susceptible rodents

- Trapping rodents for population data, serum, tissue samples and ectoparasite collections

- Conducting serosurveys of carnivore populations that consume rodents

\section{Trapping Rodents}

Systematically trapping and examining rodents is important to determine:

1) The potential hosts in an area 2) The number and kinds of fleas infesting these rodents 3 ) whether new rodent species have entered an area and 4) whether the abundance of resident rodent species has changed significantly since the previous trapping period.

Trapping is also a source of basic population ecology data, including:

1) Population densities (relative or absolute) 2) age structures and reproductive status of rodent populations 3) rodent habitat preferences and 4) local distribution.

Estimates of absolute densities of rodent populations (number of animals present per unit area) can be made using Percent trap success; a relative density estimate is more easily obtained. This quantity refers to the number of animals caught per unit effort and equals the number of rodents caught divided by the number of trapping periods, divided by the number of traps set per period, multiplied by 100 (no. animals caught/ no. trapping periods/ no. trap sets per period) $\times 100=$ percent trap success.

The no. of rodents trapped is evaluated in terms of trap positivity rate which represents the average no. of small mammals captured per traps set and may be calculated by the formula given below:

Trap positivity rate $=$ No of traps positive for rodents $/$ No of traps laid $x 100$

Flea index $=$ Total no. of flea collected/ Total no. of rats collected

\section{Format on the Details of the Rodent samples collected}

Date:

Place/ village:

SM - Suncusmurinus, RR - Rattus rattus, MM - Mus musculus, MO - Mole.

\section{Rodent Prevention}

- Sanitation

- Rodent-guards

- Illumination for rodent movement restrictions

- Pier-side inspections/surveillance on-board ships

\section{Rodent Control}

- Conventional rat cage traps

- $\quad$ Spring board traps

- Glue traps

- Electronic rat-traps

- Sherman trap

\section{Micro-level Planning}

The steps that need attention on proper planning in unit areas are indicated below:

\section{Step I: Situation Analysis}

- Species of the area

- Position of infestation

- Condition of surrounding areas

- General lay out and situation of cropping season

- Decision on control

While making situation analysis the available resources, control technology and human attitudes are to be precisely judged.

\section{Step 2: Control Design}

- Type of control

- Hygiene

- Proofing

- Chemicals/natural products to be used

- Area to be controlled

- Time of control

- $\quad$ Staff requirement, people to be involved 
Table 13.Format on the Details of the Rodent Samples Collected

\begin{tabular}{|c|c|c|c|c|c|c|c|c|c|c|c|c|}
\hline \multirow{2}{*}{$\begin{array}{l}\dot{0} \\
\text { i } \\
1 .\end{array}$} & \multirow{2}{*}{$\begin{array}{c}\text { Cage } \\
\text { Code/ } \\
\text { Place }\end{array}$} & \multirow{2}{*}{$\begin{array}{c}\text { Rodent } \\
\text { species } \\
\text { (Male/ } \\
\text { Female) }\end{array}$} & \multicolumn{3}{|c|}{ Ecto-parasites } & \multirow{2}{*}{$\begin{array}{c}\text { Ear pinna } \\
\text { collected } \\
\text { (70\% alco- } \\
\text { hol) }\end{array}$} & \multirow{2}{*}{$\begin{array}{l}\text { Blood/ } \\
\text { Serum } \\
\text { sample }\end{array}$} & \multirow[t]{2}{*}{ Smear } & \multicolumn{4}{|c|}{ Organs collected in media } \\
\hline & & & Mite & Tick & Flea & & & & Heart & Lung & Liver & Spleen \\
\hline 2. & & & & & & & & & & & & \\
\hline 3. & & & & & & & & & & & & \\
\hline
\end{tabular}

\section{Step 3: Control Preparation}

- Make a plan of action

- Inform people involved for community participation

- Obtain equipment required

- Fix dates for various phases of control action

- Prepare rodenticide baits if necessary

\section{Step 4: Rodent Control}

- Carry out control activity

\section{Step 5: Monitoring}

- All planned actions need monitoring for amending, if need arises to conform to the original plan

- This situation may require a amending in the original plan

- Check signs of activity

- Note areas which require further action

- Decide on further action and type of action

- Continue monitoring

Step 6: Maintaining Low Rodent Population Density

- Complete management actions before on set of monsoon

- They start breeding with onset of the monsoon and post monsoon months and rodent population reaches peak quickly and it becomes difficult to control them

- Use acute poison like zinc phosphide, aluminium phosphide in case of serious rodent infestations only. Legal provisions need to be considered while planning aluminium phosphide fumigation

- Use anticoagulants or other structural modification or environmental sanitation (for prevention) during low rodent density situations

- Integrating these three measures, viz., application of chemical inputs with structural modifications and clean premises/ public places, can bring maximum reduction of rodent populations

- Use bait stations wherever feasible considering their safety

\section{Timelines for implementation of the Plan}

- Conduct monthly surveys in all urban habitations like parks, open areas, drains, canals, roads, garbage dumps, office complexes

- The periodicity can also be decided based on the local situations

- However, summer months are desirable since low rodent infestation would be there at that time

- Further, on monsoon entry, bacterial diseases can flare up, and hence summer months need to be targeted for rodent vector control

\section{Data and Records Management}

\section{Conclusion}

This model action plan on the vector surveillance at the international airports/ seaports shall pave a way forward as a guiding principle for a well designed planning and effective implementation of vector surveillance and control activities. Presently, there is no proper standard operating procedure (SoP)/ guidelines for undertaking vector surveillance at activities to fulfill the obligations in terms of IHR Regulations (2005) to be implemented at international airports/ seaports. This model action plan may be useful in fulfilling the actions laid down in IHR (2005) to ensure zero tolerance for vectors at breeding/ presence the premises of international airports / seaports.

\section{Conflict of Interest: None}

\section{References}

1. WHO. International Health Regulations 2005. 2nd ed. Geneva. 2008. Available from: https://www.paho.org/ en/international-health

2. WHO Regional Office for South-East Asia. Operational guidelines on plague surveillance, Diagnosis, prevention and control. New Delhi: WHO Regional Office for SouthEast Asia. 2009b. Available from: https://apps.who.int/ iris/handle/10665/205593.

3. WHO. Equipment for vector control: specification guidelines. 2nd ed. Geneva. 2010. Available from: https://apps.who.int/iris/bitstream/hand le/10665/272410/9789241513821-eng.pdf.

4. WHO. Guidelines for testing the efficacy of insecticide products used in aircraft. Geneva. 2012a. Available 
from: https://apps.who.int/iris/handle/10665/44836.

5. WHO. Handbook for integrated vector management. Geneva. 2012b. Available from: https://iris.paho.org/ handle/10665.2/51759.

6. WHO. A global brief on vector-borne diseases. Geneva. 2014b. Available from: http://apps.who.int/ iris/bitstream/handle/10665/111008/WHO_DCO_ WHD_2014.1_eng.pdf?sequence $=1$.

7. WHO. Vector surveillance and control at ports, airports, and ground crossings. 2016. Available from: https:// www.who.int/publications/i/item/vector-surveillanceand-control-at-ports-airports-and-ground-crossings. 